tion and published four more suspense thrillers, this time under his own name. Drawing on his experience in the military and the Central Intelligence Agency as well as his extensive travels on both sides of the Iron Curtain, he wrote fast-paced, tough-talking tales of espionage, crime, and international intrigue to which he brought the same authenticity and attention to detail that marked his scholarly publications. To gather material for one of the books, Special Agent (2000), which deals with the Colombian drug trade, he and Jan traveled to Medellin-not your typical tourist destination in the late 1990s, especially for an octogenarian. The other titles in this second writing career are Quimby (1988), Beware the Pale Horse (1999), and Moscow Nights (2000). In addition, Art worked throughout his retirement as Jan's research assistant.

Another of Art's distinctions, surely unique among American Slavic specialists, is that a university street is named for him. His contribution to the development of the research park at Ohio State in the 1980s was valued so highly by the Board of Trustees that they gave his name to the park's main thoroughfare. His Ohio State colleagues as well as his family are immensely pleased to have Arthur E. Adams Drive as a point of public homage on the campus, not far from Woody Hayes Drive.

JAMES P. SCANLAN
Ohio State University
January 2008

\title{
Jan S. Adams, 1920-2007
}

Jan S. Adams, retired international studies administrator and adjunct professor of political science at Ohio State University, died at her home in Columbus on 9 December 2007, four months and three days after the death of her professional colleague and beloved husband of sixty-five years, Arthur E. Adams.

Born Ouida Janet Steckelberg in Lincoln, Nebraska, on 10 March 1920, Jan graduated cum laude and Phi Beta Kappa from the University of Nebraska in 1942 with majors in English and music. She and Art married in the same year, shortly before he enlisted in the U.S. Army. After the war, as Art did his graduate study at Cornell University, Jan devoted herself to raising their two children, Russell and Catherine, helping Art as research assistant and typist, and studying Russian informally. After the family moved to Michigan State University in 1951, Jan began graduate study in international politics with an emphasis on Russia, working with Alfred G. Meyer and others. She earned an MA in 1966 and the $\mathrm{PhD}$ in 1971, with a dissertation directed by Ellen Mickiewicz on the role of the People's Control Committee in Soviet government.

Jan was fifty when she and Art moved to Ohio State in 1970 and she began her professional career as administrator and teacher. For the first year, she was a part-time instructor in political science, but upon receipt of the $\mathrm{PhD}$ she was appointed assistant professor and director of the newly formed Center for Undergraduate International Studies, in which capacity, among other duties, she administered the new international studies major. When this center was expanded beyond undergraduate studies and renamed the Center for International Studies in 1975, Jan was again named director, a position she held until a year before her retirement, along with the title of adjunct associate professor of political science. During that last year-1985-1986 - Jan's administrative responsibilities were expanded once more when she was appointed acting vice-provost for international affairs.

What the mere enumeration of these roles does not adequately convey is that each of them required a pioneering effort on Jan's part. At each stage, she was breaking new ground at Ohio State, administratively and educationally, and laying the foundation for the complex structure of instruction and research in international studies that exists at Ohio State today. Along the way, she also took time to serve as executive secretary of the American Association for the Advancement of Slavic Studies for two contentious years, $1978-1980$.

Jan's primary interest, of course, was always Slavic studies, and from the beginning she was a driving force in the development of the field at Ohio State, as I can testify from 
personal experience. When I came to the university in 1971, George Demko warned me that I would soon be visited by a charming woman who would ask me to take on some additional teaching for an introductory course on the Soviet Union, in which guest lecturers would speak on their specialties. George said that she would explain in the nicest way that I would not be paid for this and that my department would give me no credit for it, but he predicted that her powers of gentle persuasion were so great that I would be helpless to resist. Jan came, and George was right. I thought of her recently when I heard someone describe a really good salesman in these words: "He could sell muzzles to dogs." Jan could sell extra work to college professors. In this way she assembled-without a budget!a stable of experts who, under her direction, taught one of the most popular undergraduate courses at Ohio State.

Jan's early efforts as Art's research assistant at Michigan State grew into coauthorship, the principal result of which was their joint study, Men versus Systems: Agriculture in the USSR, Poland, and Czechoslovakia (1971). At Ohio State, her first solo publications were journal articles and reviews, and in addition she edited or coedited books of readings from the Current Digest of the Soviet Press (then housed on the OSU campus) for use in her interdisciplinary course. In 1977 came her first individual book (an outgrowth of her dissertation) titled Citizen Inspectors in the Soviet Union: The People's Control Committee, which Jerry Hough described as "the first book ever written on an institution as important [to the Soviet political system] as the People's Control Committee." In retirement, with Art now doing payback as her research assistant, Jan wrote her most acclaimed work, A Foreign Policy in Transition: Moscow's Retreat from Central America and the Caribbean, 1885-1992 (1992), which received one of the AAASS "Oscars" for 1993, the Marshall Shulman prize for the best book on Russian or east European international relations. The accompanying citation described the book as "a conceptually elegant study of a little-researched area in Soviet foreign policy" and "an important concluding chapter" to the story of how the Soviet empire collapsed through overextension.

Jan and Art were a gifted pair of scholar-administrators with remarkably parallel professional lives. Both reached the vice-provost level of university administration, though it took Jan only fifteen years to do it. Both championed the cause of Slavic studies, though with different tactics, and it is difficult to say whether Art's tough love or Jan's gentle persuasion was more effective. Both were productive scholars in their chosen fields. Early on, Jan assisted Art in his research; later, Art assisted Jan. Each wrote a prize-winning book-Art's Bolsheviks in the Ukraine and Jan's A Foreign Policy in Transition-though the books came twenty-nine years apart. Their married lives were a fruitful, 65-year symbiosis, aptly symbolized by their nearly contemporaneous deaths.

James P. Scanlan Ohio State University January 2008

\section{Warren Lerner, 1929-2007}

Warren Lerner, a member of the American Association for the Advancement of Slavic Studies since its inception, died on 2 December 2007, at the age of 78 in Durham, North Carolina. He was born in Boston, Massachusetts, on 16 July 1929. Following his undergraduate education at Boston University, Warren received his MA at Columbia University's Russian Institute (now the Harriman Institute), and his doctorate in history at Columbia University where he studied under G. T. Robinson and Philip Mosley. He came to Duke University in 1961, where he joined John Curtiss and other colleagues in the history department in building one of the strongest Slavic area studies programs in the southeast. At various times Warren served as chair and director of graduate studies, and he was also a founding member of the advisory board of the Title VI National Resource Center jointly operated by the Slavic studies centers at Duke and the University of North Carolina at Chapel Hill. In 1956, he traveled to Warsaw, Moscow, Kiev, Samarkand, and Tashkent on a Ford Foundation Fellowship, making him one of the very first American scholars to have 